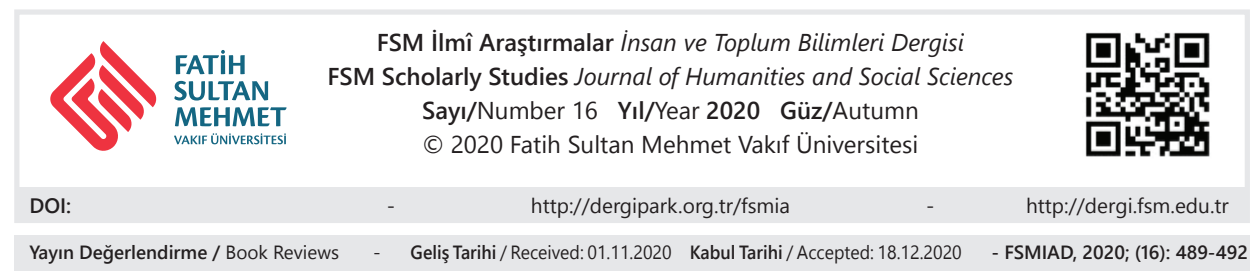

\title{
Rinaldo Marmara, Osmanlı Başkentinde Bir Levanten Semti: Galata-Pera,
}

İstanbul: Türkiye İş Bankası Kültür Yayınları, 2020, 97836254050640, $286 \mathrm{~s}$.

Esra Karadağ

Levanten bir aileden gelme bir araştırmacı olarak kaleme aldığı bu çalışmasında Rinaldo Marmara, net bir tanımı olmayan Levanten kavramını ve İstanbul'da, Galata-Pera bölgesinde yaşamış olan Levantenleri inceliyor. Marmara'nın ileri düzeydeki İtalyanca ve Fransızcası ile Osmanlı tarihçiliğinin temel sorunlarından biri olan yabancı arşivlerin yeterince kullanıl(a)maması problemini aşarak mevzubahis konu hakkında literatürdeki boşluğu doldurma gayesi kitabın en önemli özelliği olarak göze çarpıyor.

Levanten kelimesi, üzerinde hâlâ tartışmaların devam ettiği, tam olarak neyi içine aldığı yahut neyi dışarıda bıraktığı netleşmemiş, farklı şekillerde yorumlanan bir kavram olarak karşımıza çıkmaktadır. Yapılan tanımların vardığı ortak sonuç Levantenlerin köken olarak Avrupalı oldukları ve Osmanlı topraklarında yaşadıklarıdır. ${ }^{1}$ Fakat hangi dönemde yaşadıkları, tam olarak hangi milletlere mensup olduklarına dair bir görüş birliği yoktur.

Osmanlı Başkentinde Bir Levanten Semti: Galata-Pera isimli çalışmasında Rinaldo Marmara, kitabın asıl konusu olan Galata-Pera bölgesindeki Levanten

\footnotetext{
* Doktora Öğrencisi, Fatih Sultan Mehmet Vakıf Üniversitesi, İstanbul/Türkiye, esra.karadag@ stu.fsm.edu.tr, orcid.org/0000-0002-8484-7406

1 Raziye Oban Çakıcı̆̆lu, "Levanten Kavramı ve Levantenler Üzerine Bir İnceleme”, Türkiyat Araştırmaları Dergisi, sayı 22, 2007, s. 338-344.
} 
varlığına değinmeden önce herhangi bir polemiğe girmeden bu sorunsal üzerinde durmuş, ilk bölümde Levantenlerin kökeni ve tanımı hakkında bazı değerlendirmelerde bulunmuştur. Yapılan tanımların pek çoğunda zaman aralığı Osmanlı Dönemi'ni kapsarken Marmara, Levantenlerin kökenini 10. yüzyıldan itibaren ticaret yapmak için İtalyan şehir devletlerinden Konstantinopolis'e gelmeye başlayan Avrupalılara dayandırmıştır. IV. Haçlı Seferi ile birlikte Konstantinopolis'in Latin hakimiyeti altına girmesi, Avrupalıların şehirdeki sayılarını arttırmış, İstanbul'un fethine kadar şehirdeki Latin sayısı artmaya devam etmiştir. Marmara'nın Latin ve Levanten kavramlarını kendisinin de ifade ettiği gibi eş anlamlı olarak kullandığı görülmektedir. Bu topluluklar Bizans topraklarında kendilerine tahsis edilen yerlerde yaşamışlar, benzer uygulama Osmanlı Dönemi'nde de devam etmiştir. Bununla birlikte İstanbul'da yaşayan Latinlerin hukuki statüleri yeniden düzenlenmiştir. Bu noktada Marmara, Levantenlerin aslında kim oldukları hakkında klâsik tanımlamalardan farklı bir değerlendirmede bulunmuştur. Latinler, Osmanlı Latinleri ve yabancı Latinler olmak üzere ikiye ayrılmış ve bu ayrım her iki cemaatin farklı hukuki statülerde değerlendirilmesini gerektirmiştir. Osmanlı tebaasındakiler Ceneviz mahallesi olan Galata'nın teslimi esnasında yerlerinde kalanlardır. Yabancılar ise İstanbul'un fethinin ardından yaşadıkları yeri terk edip sonrasında şehre yeniden dönenler ve yabancı olarak Osmanlı topraklarına yeni gelenleri ifade etmektedir. Marmara, Levantenlerin yabancı Latinler olduğunu, Osmanlı tebaasından olan Latin cemaatin Levanten sayılamayacağını defaatle belirtmiştir. Fakat kendisinin de belirttiği gibi bu fark zamanla unutulmuş ve bu iki cemaatin birbirine karışması Levanten kavramını bu iki grubu da içine alacak şekilde genişletmiştir.

Rinaldo Marmara'nın, kitabın asıl konusu olan ikinci ve üçüncü bölümleri zengin arşiv verileriyle oluşturduğu görülüyor. 1913 Doğu Yıllığı'ndan yararlanılarak Pera bölgesinde bulunan sokakların isimleri, buralarda yaşamış Levantenlerin adları ve icra ettikleri meslekler listeleniyor. Marmara böylelikle Pera'nın 19. yüzyıldaki sosyal topoğrafyasının çizildiğinin ve bu verilerin şimdilerde var olmayan birçok eski yapının yerlerinin saptanmasında oldukça önemli olduğunun altını çiziyor. Bununla birlikte İstanbul Fransisken Konventual Arşivleri'nde yer alan bilgilere dayanarak 1904 yılında Pera'da yaşayan Latinlerin isimleri ve hane numaraları da sıralanıyor. Tüm bunlar Rinaldo Marmara'nın ciddi bir arşiv mesaisi yaptığını gösteriyor hiç şüphesiz. Galata başlığına geldiğimizde ise daha farklı bir anlatı karşımıza çıkıyor. Galata Kulesi'nin nasıl inşa edildiği ve geçtiği merhalelerden söz edildikten sonra Galata'da bulunan başlıca kiliseler tanıtılıyor. Rinaldo Marmara tıpkı Pera'da olduğu gibi Galata'nın da sosyal topoğrafyasının verileceğini söylüyor fakat bölüm "Galata'daki İtalyanların Ticari Faaliyetleri” 
başlığı ile son buluyor. Galata'daki İtalyanların ticari faaliyetleri hakkındaki bilgiler merak uyandırıyor. Örneğin İstanbul'da ilk eczanenin İtalyanlar tarafından açılmış olması, bu mesleği icra eden İtalyanların isimlerinin zikredilmesi, 1sıtma ürünleri, enstrüman, mobilya, halı gibi ürünlerde İtalyan etkisinin anlatılması gibi hususlar çalışmayı zenginleştiriyor.

Kitap genel olarak bir sosyal tarih çalışması izlenimi veriyor. Levantenlerin gündelik hayatına, dillerine, kıyafetlerine, inançlarına, İmparatorluk'ta yaşayan diğer gayrimüslimlerden olan farklılıklarına vb. hususlara dair detaylı bir anlatı beklentisi hasıl oluyor okuyucuda. İlk bölümde tanımlar, ikinci bölümde tablolaştırılmış bilgilerle karşılaşan okur üçüncü bölümde gündelik hayatta Levantenleri somut örnekler üzerinden görmek istiyor. Levantenlerin ortak dili olan Rumcaya değinilmiş olması, Galata-Pera' daki dini geleneklerden örnekler sunulması, derneklerinin işleyişlerinden bahsedilmesi ilgi çekici görünse de tadımlık bilgiler olarak kalıyor. "Levantenlerin Toplumsal Hayatı, Dernekler" başlığı sadece on sayfada anlatıliyor.

Kitabın ekler kısmında Fortunato Maresia isimli Levanten bir araştırmacının Levantenlerle ilgili bir panelde yapmış olduğu konuşmanın metnine yer veriliyor. Burada Levantenlerin yaşam tarzları hakkında birinci ağızdan bilgilere ulaşıyoruz. Yine ekler bölümünde Rinaldo Marmara'nın kişisel fotoğraf arşivi ile Latin-Katolik Kiliseler Arşivi’nden sunduğu fotoğraflar çalışmayı görsel anlamda değerli kıliyor.

Yazarın kitabında pek çok kere tekrarladığı "Levantenler Osmanlı İmparatorluğu'nda doğan, Osmanlı topraklarında hayatlarını sürdüren yabancı uyruklulard1. Osmanlı tebaasından gayrimüslimleri veya reayayı bu gruba dahil etmek tarihi bir hatadır"2 tanımı ilgi çekicidir. Zira çalışmada bu ayrımın sınırlarını çizecek kadar bilgi verilmemiştir. Örneğin Osmanlı Latinlerinin tebaadan sayılması fakat bununla birlikte bir millet olarak görülmemesi, nasıl idare edildikleri hususunda zihinlerde soru işareti bırakmaktadır. Onların kapitülasyonlar yoluyla idare edilen ve "gerçek Levanten olarak tanımlanan yabancı Latinlerden ne gibi farkları vardı?" sorusunun cevabı yeterince verilmemiştir. Bu durum "gerçek Levantenlerin" de kimler olduğu hususunda bir boşluk yaratmaktadır. Bu sebeple Osmanlı Latinlerinin hangi farklardan dolayı Levanten olarak görülmediği bu tanımlamanın içerisinde daha geniş bir çerçevede ele alınmalıdır. İkinci bölüme bakıld1ğında ise okuyucu tablo halinde sunulmuş bir bilgi yığını ile karşılaşmaktadır.

2 Rinaldo Marmara, Osmanlı Başkentinde Bir Levanten Semti Galata-Pera, İstanbul, İş Bankası Kültür Yayınları, 2020, s. 33. 
Bir tarih çalışmasında veriler kadar verilerin analiz edilmesi ve yorumlanmasının da önemli bir husus olmasından ötürü çalışma bu yönüyle eksik görünmektedir. Okur tüm bu bilgilerle ne yapacağı sorusu ile baş başa kalmaktadır böylece. Yine de yapılacak diğer çalışmalara -bilhassa şehir tarihi çalışmalarına- 1şık tutması açısından bakıldığında Rinaldo Marmara'ya hakkının teslim edilmesi gerekir çünkü bu bilgiler bir başka araştırmaya önemli bir veri desteği sunacaktır.

Rinaldo Marmara'nın bu çalışmayı kaleme almak için Vatikan Gizli Arşivi, Propaganda Fide Tarihi Arşivi ve muhtelif kiliselerin arşivlerini kullanarak daha önce gün yüzüne çıkmamış belgeler üzerinden bir araştırma yapmış olması kuşkusuz çalışmanın en kıymetli yanlarından biri okuyucular için. Türkiye'de yapılan akademik çalışmalarda olan bitenin öteki dünyadaki yansımalarını izlemek, uzun bir dönem yabancı arşivlerin neredeyse yok sayılmasıyla ile pek mümkün görünmüyordu. Yapılan yeni araştırmalarla birlikte bu eksikliği giderme hususunda önemli bir aşama kat edilmeye başlandı. Marmara'nın bu çalışması da mevzubahis boşluğun doldurulması adına kendi alanında büyük bir takdiri hak ediyor. Fakat bununla birlikte yazarın Osmanlı Arşivleri’ni neden kullanmadığ da akıllarda soru işareti bırakıyor. Levantenlerin varlığını içinde yaşadıkları devletin arşiv kayıtlarında bulmak da okuyucu için yukarıdaki soruları açıklar ve boşlukları doldurur nitelikte olurdu hiç şüphesiz. Öte yandan Rinaldo Marmara'nın kendi çalışmasının tercümanı olması oldukça önemli bir detay olarak göze çarpıyor, zira çoğunlukla Fransızca ve İtalyanca belgelerden faydalanarak oluşturduğu eseri Türkçe olarak yayımlamış olması akademik bir yayında çeviri sorununu aşarak kitabı daha keyifle okunur bir hale getiriyor. 